\title{
Türkiye'nin Derecelendirme Notları Ve Kredi Temerrüt Swap Primlerinin Ekonomik Ve Sosyal Olaylara Tepkisinin Analizi'
}

Bekir KAYA ${ }^{2}$ - Emine ÖNER KAYA ${ }^{3}$ - Kürșat YALÇINER ${ }^{4}$

Makale Gönderim Tarihi: 25.10.2014

Makale Kabul Tarihi: 12.03.2015

\section{ÖZ}

Kredi derecelendirme notları ve kredi temerrüt swap primleri bir ülkenin kredi riskinin ölçülmesinde iki temel göstergedir. Ekonomik ve sosyal olaylara verilen tepkinin ölçülmesi hangi göstergenin ülke riskini yansıtmada daha etkin olduğunu test etme imkânı sağlamaktadır. Çoklu doğrusal regresyon yöntemi ve günlük veriler kullanılarak, 01.01.2007 ile 22.04.2014 tarihleri arasındaki dönemin, Türkiye ölçeğinde analiz edildiği çalıșmada, derecelendirme notları ve CDS primlerinin aynı olaylara her zaman aynı tepkiyi vermediği tespit edilmiștir.

Anahtar Kelimeler: Kredi Temerrüt Swap Primi, Derecelendirme Notu, Çoklu Doğrusal Regresyon

1 18. Finans Sempozyumu'nda sunulan "Türkiye'nin Derecelendirme Notları ve Kredi Temerrüt Swap Primlerinin Ekonomik ve Sosyal Olaylara Tepkisinin Analizi" isimli bildiriden türetilmiștir.

2 Öğr. Gör., Gazi Üniversitesi, Polatlı Sosyal Bilimler MYO, Gazi Üniversitesi Gölbașı Yerleșkesi, Gölbașı, Ankara, e-posta: bekirkaya@gazi.edu.tr

3 Yrd. Doç. Dr., Gazi Üniversitesi, Bankacılık ve Sigortacılık Yüksekokulu, İncitașı Caddesi, No:4, Kat:4, (Hukuk Fakültesi Binası) Beșevler, Ankara, e-posta: emineoner@gazi.edu.tr

4 Prof. Dr., Gazi Üniversitesi, İktisadi ve İdari Bilimler Fakültesi, İncitașı Caddesi, No:4, Beșevler, Ankara, e-posta: yalciner@gazi.edu.tr 


\section{ANALYSIS OF THE RESPONSES OF TURKEY'S RATINGS AND CREDIT DEFAULT SWAP SPREADS TO THE ECONOMIC AND SOCIAL EVENTS}

\section{ABSTRACT}

Credit ratings and credit default swap spreads are two main indicators for the measurement of a country's credit risk. Measurement of the response to the economic and social events provide the opportunity to test which indicator is more effective to reflect country risk. By using multiple linear regression method and daily data, it was determined that ratings and credit default swaps are not always give the same response to the same events for the period between January 1, 2007 and April 22, 2014 in Turkey.

Keywords: Credit Default Swap Spread, Credit Rating, Multiple Linear Regression

\section{Gíriș}

Kredi değerliliğinin belirlenmesinde uzun yıllardan beri kullanılan fakat son zamanlarda güvenilirliğine dönük yapılan tartıșmalarla gündemden düșmeyen araçlardan biri, çeșitli kurum ve kurulușlara, șirketlere ve ülkelere verilen derecelendirme notlarıdır. Son dönemlerde șirket ve ülkelerin kredi değerliliğinin tespitinde kullanılmaya bașlayan ve kullanım alanı giderek daha da genișleyen, hatta belki de derecelendirme notlarına bir alternatif olarak değerlendirilebilecek enstrümanlardan bir diğeri ise, kredi temerrüt swap (CDS) primleridir. Kredi değerliliğinin tespitinde kullanılabilecek derecelendirme notları ve CDS primlerinin hangisinin meydana gelen ekonomik ve siyasi olayları yansıtan iyi bir gösterge olduğunun belirlenmesi önem arz etmektedir.

Bu çalıșmanın amacı, ülke kredi derecelendirme notları ile CDS primleri arasındaki etkileșimin Türkiye ölçeğinde örnek olaylarla incelenmesidir. Çalıșmada, seçilen dönem içerisinde Türkiye'de ortaya çıkan veya dünyada ortaya çıktığı halde Türkiye'yi de etkileyen çeșitli ekonomik, siyasi ve sosyal gelișmelerin ve olayların, ülke derecelendirme notları ve CDS primleri üzerindeki etkisi incelenmektedir. 


\section{Literatür Taraması}

Derecelendirme notları ile CDS primleri arasındaki etkileșimi inceleyen çalıșmalara, CDS sözleșmelerinin yoğun bir biçimde kullanılması ile birlikte, 2000'li yıllardan sonra rastlanmaktadır. Yapılan her çalıșma, bu etkileșimi ya da kredi değerliliğinin ölçülmesi nokłasında her iki aracın gösterdiği bașarıyı, șirketler veya ülkeler ölçeğinde çeșitli açılardan test etmek suretiyle gerçekleștirilmektedir.

Lehnert ve Neske (2006) tarafından yapılan çalıșmada ise, fiili not düșüșlerinin önemli bilgi içerdiği, farklı derecelendirme duyurularının piyasalarca öngörülemediği, pozitif ya da durağan görünüm raporlarının duyuru sonrası CDS primleri üzerinde önemli bir etkisi olduğu ve negatif görünüm raporları ile not düșüșlerinin piyasalar tarafından birbirinden bağımsız olaylar olarak kabul edildiği tespitlerine ulașılmıștır.

Micu, Remolona ve Wooldridge (2006), daha önce yaptıkları çalıșmayı geliștirmek suretiyle derecelendirme duyurularının CDS primleri üzerindeki etkisini incelemiștir. Yapılan analiz sonucunda, her tür derecelendirme duyurusunun, görünüm-gözden geçirme-derecelendirme notu değișikliği (pozitif ya da negatif) olduğuna bakılmaksızın, CDS primleri üzerinde önemli bir etkisi olduğu tespit edilmiștir.

Ersan ve Günay (2009) tarafından yapılan çalıșmada, 14 Mart 2008'de açilan ve 30 Temmuz 2008'de karara bağlanan iktidar partisinin kapatılmasına ilișkin davanın, Dow Jones endeksinin, 2030 vadeli Türkiye gösterge eurobond faizinin, Türkiye yurt içi gösterge faizinin ve BIST 100 endeksi volatilitesinin Türkiye'nin CDS primleri üzerinde istatistiksel olarak anlamlı bir etkisinin olup olmadığı analiz edilmiștir. Ulașılan sonuçlara göre, kapatma davasının Türkiye'nin CDS primleri üzerinde anlamlı bir etkisi olmadığı sonucuna ulașılmıștır. Bununla birlikte Türkiye'nin CDS primleri üzerinde etkili olan değișkenlerin, Türkiye'deki yurt içi değișkenlere nazaran yurt dıșında ișlem gören eurobondlara ait getiriler ile Dow Jones endeks getirisi gibi yurt dıșı değișkenler olduğu tespit edilmiștir. 
Jacobs, Karagözoğlu ve Peluso (2010) tarafindan gerçekleștirilen çalıșmada, CDS primleri ile derecelendirme notları arasındaki ilișkinin kredi riskinin fiyatlanması ve piyasa katılımcılarının algılarının açıklanması noktasındaki etkisi incelenmiștir. Elde edilen sonuçlar, kredi kalitesini ölçen değișkenlerin farkları ile kredi derecelendirmeleri arasında istatistiksel açıdan anlamlı farklılıklar olduğunu göstermiștir. Gözlemlenen farklılıklar, kredi kalitesi yanı sıra borsa getirileri ve kısa ve uzun dönem faiz oranlarıyla kısmen de olsa açıklanabilmiștir. Buna rağmen ulașılan sonuçlar, CDS primleri ile kredi derecelendirmeleri arasındaki farkların önemli bir kısmının sadece piyasa ya da sadece referans varlıkla ilgili değișkenlere bağlanamayacağını göstermiștir.

Ismailescu ve Kazemi (2010)'nin çalıșmasında, ülke notu değișimlerine karșı gelișmekte olan piyasa CDS primlerinin tepkisi ölçülmüștür. Bu çalıșmada dikkat çekilmesi gereken noktalardan biri, Standard \& Poor's Rating Services'den sağlanan derecelendirme notlarının 1'den 17'ye kadar, 1'in en düșük düzeyi, 17'nin ise en yüksek düzeyi ifade ettiği bir ölçeğe dönüștürülmesidir. Yapılan analizlerde, pozitif olayların meydana geldiği 2 gün içerisinde CDS piyasaları üzerindeki etkisinin ortaya çıktığı ve diğer gelișmekte olan ülkelere daha fazla yayılma etkisi gösterdiği tespit edilmiștir. Ayrıca CDS piyasaları negatif olayları öngörmüș ve CDS primlerindeki önceki değișiklikler negatif kredi nołu değișimlerinin tahmininde de kullanılmıștır.

Flannery, Houston ve Partnoy (2010) tarafindan yapılan çalıșmada, kredi derecelendirme notları yerine CDS primlerinin kullanılabilirliği analiz edilmiștir. Calıșmada son mali krizin etkilerinin belirgin bir șekilde hissedildiği 15 büyük finansal kurulușun finansal yükümlülüklerinin bir dayanağı olan CDS primleri üzerine yoğunlașılmıș olup, CDS primlerinin kredi derecelendirme notlarına nazaran daha doğru ve hızlı bir șekilde bilgi yansıttığı tespit edilmiștir.

Papaioannou (2011), çalıșmasında, CDS primleri üzerinde kredi derecelendirme duyurularına karșı ekonomik ve piyasa faktörlerinin etkisini incelemiștir. Elde edilen sonuçlara göre, CDS'ler bir gösterge niteliği tașıdığından, ekonomik faktörler ya da kredi 
derecelendirme duyurularına nazaran piyasa faktörleri ile daha fazla ilișkilidir.

Castellano ve Giacometti (2012) tarafından yapılan çalıșmada, parametrik olmayan haritalama ile CDS primlerine dayalı bir derecelendirme notu ölçeği olușturulmakta olup, derecelendirme kurulușlarınca verilen notlar ile bu model karșılaștırılmıștır. 103.804 CDS sözleșmesinin yer aldığı analizde olușturulan derecelendirme notu ölçeği ile derecelendirme kurulușlarınca hazırlanan derecelendirme notu ölçeği arasında bir hiza olduğu tespit edilmiștir. Bu hiza, finansal kriz yıllarının olduğu dönemlerde daha da belirginleșmiștir. Kriz öncesi dönemde ABD piyasasına nazaran Avrupa CDS piyasasıyla ilgili olușturulan derecelendirme notları, derecelendirme kurulușlarınca olușturulan derecelendirme notlarıyla daha bağlantılıdır.

Finnerty, Miller ve Chen (2013) tarafından yapılan çalıșmada, kredi derecelendirme duyurularını CDS primleri üzerindeki etkisi incelenmișțir. Standart olay analiz yönteminin kullanıldığı çalıșmada, șirketlerin derecelendirme notlarındaki artıșların CDS primleri üzerinde önemli bir etkisi olduğu belirlenmiștir. Fakat derecelendirme notlarındaki azalıșların bir etkisi bulunmamıștır.

\section{III. Çalıșmanın Literatüre Katkısı}

Çalıșmanın literatüre katkısı, Türkiye'deki ve dünyadaki gelișmeler çerçevesinde, hem derecelendirme kurulușları tarafından Türkiye'ye verilen derecelendirme notlarının hem de Türkiye'nin CDS primlerinin, ülke kredi değerliliği üzerindeki etkinliğinin ölçülmesidir. Diğer bir ifadeyle, her iki göstergenin etkinliği de, belirlenen dönem içerisindeki olaylara verilen tepkiler açısından ölçülmektedir. Böylelikle, her iki göstergenin Türkiye'nin ülke kredi değerliliğini doğru, hızlı ve zamanında yansıtma noktasındaki bașarısı da test edilmiș olmaktadır.

\section{Veri Kümesi ve Değișkenlerin Tanımlanması}

Türkiye'deki veya dünyadaki ekonomik ve sosyal gelișmelerin, Türkiye'nin CDS primleri ve derecelendirme notları üzerindeki etkisinin incelendiği bu çalıșma, 01.01.2007 ile 22.04.2014 ta- 
rihi arasındaki dönemi kapsamaktadır. Analizde kullanılan değișkenler Tablo 1'de gösterilmektedir.

Tablo 1. Analizde Kullanılan Değișkenler

\begin{tabular}{|c|c|c|}
\hline & Kodu & Değișkenler \\
\hline \multirow{4}{*}{$\begin{array}{l}\text { Bağımlı } \\
\text { Değișken- } \\
\text { ler }\end{array}$} & CDS_DEG & $\begin{array}{l}\text { Türkiye'nin \$ Cinsinden } 5 \text { Yıl Vadeli CDS Primlerindeki } \\
\text { Değișim }\end{array}$ \\
\hline & S\&P_DEG & $\begin{array}{l}\text { Standard \& Poor's Rating Services Tarafından Türkiye'ye } \\
\text { Verilen Uzun Dönem Yabancı Para Birimi Cinsi Egemen } \\
\text { Ülke Kapsamlı Derecelendirme Notu Değișimi }\end{array}$ \\
\hline & $\begin{array}{l}\text { MOODYS } \\
\text { DEG }\end{array}$ & $\begin{array}{l}\text { Moody's Corporation Tarafindan Türkiye'ye Verilen Uzun } \\
\text { Dönem Yabancı Para Birimi Cinsi Egemen Ülke Kapsamlı } \\
\text { Derecelendirme Notu Değișimi }\end{array}$ \\
\hline & FITCH_DEG & $\begin{array}{l}\text { Fitch Ratings Tarafından Türkiye'ye Verilen Uzun Dönem } \\
\text { Yabancı Para Birimi Cinsi Egemen Ülke Kapsamlı Derece- } \\
\text { lendirme Notu Değișimi }\end{array}$ \\
\hline \multirow{8}{*}{$\begin{array}{l}\text { Bağımsız } \\
\text { Değișken- } \\
\text { ler }\end{array}$} & $\mathrm{X} 1$ & İyi Olay \\
\hline & $\mathrm{X} 2$ & Kötü Olay \\
\hline & X3 & Siyasi Olay \\
\hline & $\mathrm{X} 4$ & Ekonomik Olay \\
\hline & X5 & Yurt İçi l̇yi Olay \\
\hline & X6 & Yurt Dıșı lyi Olay \\
\hline & $\mathrm{X7}$ & Yurt İçi Kötü Olay \\
\hline & $\mathrm{x} 8$ & Yurt Dıșı Kötü Olay \\
\hline
\end{tabular}

Analizde kullanılan bağımlı değișkenlerden ilki, Türkiye'nin \$ cinsinden 5 yıl vadeli CDS sözleșmelerine dayalı yayımlanan primlerindeki değișimdir. Farklı vadelerde CDS sözleșmeleri ișlem görmesine rağmen, 5 yıl vadeli CDS sözleșmelerinin kullanılmasının nedeni, bu sözleșmelerin büyük çoğunluğunun 5 yıllık süreyi kapsayan CDS sözleșmeleri olmasıdır. Günlük olarak yayımlanmakta olan CDS verileri, Bloomberg veri sağlayıcısından temin edilmektedir. CDS verilerindeki günlük değișimler ise, her güne ait veriden önceki günün verisi çıkarılarak bulunmaktadır.

Analizde kullanılan bağımlı değișkenlerden diğeri ise, bașlıca üç derecelendirme kurulușu (Standard \& Poor's Rating Service, Moody's Corporation ve Fitch Ratings) tarafından uzun vadeli yabancı para birimi cinsi yükümlülükler için Türkiye'ye verilen 
egemen ülke derecelendirme notu ve görünümlerinin yer aldığı kapsamlı derecelendirme notlarıdır.

Derecelendirme kurulușlarınca olușturulan not ölçekleri birbirinden farklılașmaktadır. Bu farklılașmayı bir bütün halinde görebilmek için derecelendirme kurulușları tarafından uzun vadeli yabancı para birimi cinsi yükümlülüklerin yerine getirilmesine ilișkin olușturulan not ölçekleri Tablo 2'de gösterilmektedir.

Tablo 2. Derecelendirme Kurulușlarınca Olușturulan Uzun Vadeli Yabancı Para Birimi Cinsi Yükümlülüklere İlișkin Derecelendirme Notu Ölçekleri

\begin{tabular}{|c|c|c|}
\hline Standard \& Poor's Rating Services & Moody's Corporation & Fitch Ratings \\
\hline AAA & $\mathrm{Aaa}$ & $\mathrm{AAA}$ \\
\hline $\mathrm{AA}$ & $\mathrm{Aa}$ & $\mathrm{AA}$ \\
\hline $\mathrm{A}$ & $\mathrm{A}$ & $\mathrm{A}$ \\
\hline $\mathrm{BBB}$ & $\mathrm{Baa}$ & $\mathrm{BBB}$ \\
\hline $\mathrm{BB}$ & $\mathrm{Ba}$ & $\mathrm{BB}$ \\
\hline $\mathrm{B}$ & $\mathrm{B}$ & $\mathrm{B}$ \\
\hline $\mathrm{CCC}$ & $\mathrm{Caa}$ & $\mathrm{CCC}$ \\
\hline $\mathrm{CC}$ & $\mathrm{Ca}$ & $\mathrm{CC}$ \\
\hline R & $\mathrm{C}$ & $\mathrm{C}$ \\
\hline SD ve D & & $\mathrm{RD}$ \\
\hline & & $\mathrm{D}$ \\
\hline
\end{tabular}

Kaynak: Fitch Rating, 2014, Definitions of Ratings and Other Forms of Opinion, s.9-10; Moody's Investor Services, 2014, Rating Symbols and Definitions, s.5; Standard \& Poor's Rating Services, https://www.globalcreditportal.com/ratingsdirect/renderArticle.do? articleld=1019442\&SctArtld=147045\&from=CM\&nsl_code=LIME, Erișim Tarihi: 21 Mart 2014.

Derecelendirme kurulușlarının not ölçekleri bir harf sistemine dayandırılmaktadır. Bununla birlikte, derecelendirme kurulușlarından Standard \& Poor's Rating Services bu not ölçeğini AA ile CCC arasındaki notlara + ve - ișaretler vermek suretiyle, Moody's Corporation Aa ile Ca arasındaki notlara 1, 2, 3 șeklinde numara vermek suretiyle ( 1 en yüksek durumu, 3 ise en düșük durumu ifade etmektedir), Fitch Rating ise AA ile B arasındaki notlara + ve 
- ișaretler vermek suretiyle genișletmektedir. Bu șekilde ölçeklerin daha hassas ölçümler yapabilmesi sağlanmaktadır. Bu doğrultuda derecelendirme kurulușlarının genișletilmiș not ölçekleri Tablo 3’te yer almaktadır.

Derecelendirme kurulușları tarafından ülkelerin derecelendirilmesinde Tablo 3'teki not ölçekleri kullanılmakla birlikte, not değișimleri çok sık gerçekleșmemektedir. Derecelendirme kurulușlarınca yapılan daha kısa dönemli değerlendirmelerin neticesi not değișimi olarak değil de izlem değișimi ya da görünüm değișimi șeklinde gerçekleșmektedir. Derecelendirme kurulușları uzun dönem için derecelendirme notlarını, orta vade dönemler için not görünümlerini ve daha kısa dönemli değerlendirmeler için ise not izlemlerini kullanılmaktadır. Bu açıdan yapılan analizde derecelendirme kurulușlarının derecelendirme notları yanında not görünümleri ve not izlemleri birlikte değerlendirilmekte ve analize dâhil edilmektedir. Fakat Tablo 3 'te yer aldığı üzere derecelendirme notları bu durumlarda dahi bir harf sisteminden öteye gidememektedir.

Tablo 3. Derecelendirme Kurulușlarınca Olușturulan Uzun Vadeli Yabancı Para Birimi Cinsi Yükümlülüklere İlișkin Genișletilmiș Derecelendirme Notu Ölçekleri

\begin{tabular}{|c|c|c|}
\hline Standard \& Poor's Rating Services & Moody's Corporation & Fitch Ratings \\
\hline AAA & Aaa & AAA \\
\hline AA+ & Aal & AA+ \\
\hline AA & Aa2 & AA \\
\hline AA- & $\mathrm{Aa} 3$ & $\mathrm{AA}-$ \\
\hline$A+$ & $\mathrm{A} 1$ & $\mathrm{~A}+$ \\
\hline $\mathrm{A}$ & $\mathrm{A} 2$ & $\mathrm{~A}$ \\
\hline $\mathrm{A}-$ & $\mathrm{A} 3$ & $\mathrm{~A}-$ \\
\hline $\mathrm{BBB}+$ & $\mathrm{Baa} 1$ & $\mathrm{BBB}+$ \\
\hline $\mathrm{BBB}$ & $\mathrm{Baa} 2$ & $\mathrm{BBB}$ \\
\hline $\mathrm{BBB}-$ & $\mathrm{Baa} 3$ & $\mathrm{BBB}-$ \\
\hline $\mathrm{BB}+$ & $\mathrm{Ba} 1$ & $\mathrm{BB}+$ \\
\hline $\mathrm{BB}$ & $\mathrm{Ba} 2$ & $\mathrm{BB}$ \\
\hline $\mathrm{BB}-$ & $\mathrm{Ba} 3$ & $\mathrm{BB}-$ \\
\hline
\end{tabular}




\begin{tabular}{|c|c|c|}
\hline $\mathrm{B}+$ & $\mathrm{B} 1$ & $\mathrm{~B}+$ \\
\hline $\mathrm{B}$ & $\mathrm{B} 2$ & $\mathrm{~B}$ \\
\hline $\mathrm{B}-$ & $\mathrm{B} 3$ & $\mathrm{~B}-$ \\
\hline $\mathrm{CCC}+$ & $\mathrm{Caa} 1$ & $\mathrm{CCC}$ \\
\hline $\mathrm{CCC}$ & $\mathrm{Caa} 2$ & $\mathrm{CC}$ \\
\hline $\mathrm{CCC}-$ & $\mathrm{Caa} 3$ & $\mathrm{C}$ \\
\hline $\mathrm{CC}$ & $\mathrm{Ca} 1$ & $\mathrm{RD}$ \\
\hline $\mathrm{R}$ & $\mathrm{Ca} 2$ & $\mathrm{D}$ \\
\hline SD ve D & $\mathrm{Ca} 3$ & \\
\hline & $\mathrm{C}$ & \\
\hline
\end{tabular}

Kaynak: Fitch Rating, 2014, Definitions of Ratings and Other Forms of Opinion, s.9-10; Moody's Investor Services, 2014, Rating Symbols and Definitions, s.5; Standard \& Poor's Rating Services, https://www.globalcreditportal.com/ratingsdirect/renderArticle.do? articleld $=1019442 \& S c t$ Artld $=147045 \&$ from $=$ CM\&nsl_code $=$ LIME, Erișim Tarihi: 21 Mart 2014.

Türkiye'nin CDS primlerindeki değișimin günlük sayısal veriler olduğu düșünüldüğünde olușturulan zaman serisi verileriyle bu verilerin uyumunu bu șekliyle sağlamak mümkün olmamaktadır. Bu sorunun ortadan kaldırılması için, Ismailescu ve Kazemi (2010) ile Gande ve Parsley (2005)'in çalıșmasında olduğu gibi rakamsal ibareler ile ifade edilen not ölçeklerine dönüștürme yolu tercih edilmektedir. Bu kapsamda olușturulan kapsamlı derecelendirme notu ölçekleri Tablo $4^{\prime}$ te yer almaktadır. 
Tablo 4. Derecelendirme Kurulușlarınca Olușturulan Uzun Vadeli Yabancı Para Birimi Cinsi Yükümlülüklere Ilișkin Kapsamlı Derecelendirme Notu Ölçeği

\begin{tabular}{|c|c|c|c|c|c|}
\hline $\begin{array}{c}\text { Standard \& Poor's } \\
\text { Rating Services Not } \\
\text { Ölçeği }\end{array}$ & $\begin{array}{l}\text { Standard \& Poor's } \\
\text { Rating Services } \\
\text { Kapsamlı Not Ölçeği }\end{array}$ & $\begin{array}{l}\text { Moody's } \\
\text { Corporation } \\
\text { Not Ölçeği }\end{array}$ & $\begin{array}{c}\text { Moody's } \\
\text { Corporation } \\
\text { Kapsamlı Not } \\
\text { Ölçeği }\end{array}$ & $\begin{array}{l}\text { Fitch Ratings } \\
\text { Not Ölçeği }\end{array}$ & $\begin{array}{c}\text { Fitch Ratings } \\
\text { Kapsamlı Not } \\
\text { Ölçeği }\end{array}$ \\
\hline AAA & 23 & Aaa & 23 & AAA & 21 \\
\hline $\mathrm{AA}+$ & 22 & $\mathrm{Aal}$ & 22 & $\mathrm{AA}+$ & 20 \\
\hline $\mathrm{AA}$ & 21 & $\mathrm{Aa} 2$ & 21 & $\mathrm{AA}$ & 19 \\
\hline AA- & 20 & Aa3 & 20 & AA- & 18 \\
\hline $\mathrm{A}+$ & 19 & $\mathrm{Al}$ & 19 & $A+$ & 17 \\
\hline A & 18 & $\mathrm{~A} 2$ & 18 & A & 16 \\
\hline A- & 17 & A3 & 17 & A- & 15 \\
\hline $\mathrm{BBB}+$ & 16 & Baal & 16 & $\mathrm{BBB}+$ & 14 \\
\hline BBB & 15 & Baa2 & 15 & BBB & 13 \\
\hline BBB- & 14 & Baa3 & 14 & BBB- & 12 \\
\hline $\mathrm{BB}+$ & 13 & $\mathrm{Bal}$ & 13 & $\mathrm{BB}+$ & 11 \\
\hline BB & 12 & $\mathrm{Ba} 2$ & 12 & BB & 10 \\
\hline BB- & 11 & $\mathrm{Ba} 3$ & 11 & BB- & 9 \\
\hline $\mathrm{B}+$ & 10 & B1 & 10 & $\mathrm{~B}_{+}$ & 8 \\
\hline B & 9 & B2 & 9 & B & 7 \\
\hline B- & 8 & B3 & 8 & B- & 6 \\
\hline $\mathrm{CCC}+$ & 7 & Caal & 7 & $\mathrm{CCC}$ & 5 \\
\hline $\mathrm{CCC}$ & 6 & Caa2 & 6 & $\mathrm{CC}$ & 4 \\
\hline CCC- & 5 & Caa3 & 5 & $C$ & 3 \\
\hline $\mathrm{CC}$ & 4 & $\mathrm{Cal}$ & 4 & $R D$ & 2 \\
\hline C & 3 & $\mathrm{Ca} 2$ & 3 & D & 1 \\
\hline$R$ & 2 & $\mathrm{Ca} 3$ & 2 & & \\
\hline$S D$ ve $D$ & 1 & C & 1 & & \\
\hline \multicolumn{2}{|l|}{ Pozitif not görünüm } & 0,50 & & & \\
\hline \multicolumn{2}{|l|}{ Pozitif not izlemi } & 0,25 & & & \\
\hline \multicolumn{2}{|l|}{ Durağan not görünümü } & 0 & & & \\
\hline \multicolumn{2}{|l|}{ Negatif not izlemi } & $-0,25$ & & & \\
\hline \multicolumn{2}{|l|}{ Negatif not görünümü } & $-0,50$ & & & \\
\hline
\end{tabular}

Kaynak: Derecelendirme kurulușlarının notları, görünümleri ve izlemleri dikkate alınarak tarafımızca olușturulmuștur.

Tablo 4 'te olușturulan puanlama sisteminde derecelendirme notları için 1 puan en düșük seviyeyi; derecelendirme kurulușlarının not ölçekleri farklı olduğundan Standard \& Poor's Rating Servi- 
ces için 23 puan, Moody's Corporation için 23 puan ve Fitch Ratings için ise 21 puan en yüksek seviyeyi ifade etmektedir. Ayrıca derecelendirme notu görünümü ile ilgili olarak pozitif görünüm durumunda not puanının 0,50 puan artırılması, negatif görünüm durumunda not puanının 0,50 puan azaltılması, durağan görünüm durumunda ise not puanının değiștirilmemesi yoluna gidilmektedir. Ayrıca not izlemleri de not puanı üzerinde 0,25 puanlık bir katsayı ile etki yapmaktadır. Yani pozitif not izlemi olması durumunda not puanı 0,25 puan artırılmakta, negatif not izlemi olması durumunda ise not puanı 0,25 puan azaltılmaktadır. Bu kapsamda yapilan puanlamaya bir örnek vermek gerekirse, Türkiye'nin derecelendirme notu Standard \& Poor's Rating Services'e göre BB+ ve not görünümü ise negatif olduğunda derecelendirme notu için 13 puan, not görünümü için ise $-0,50$ puan dikkate alındığında, Türkiye'nin kapsamlı derecelendirme notu 12,5 puan olmaktadır. Olușturulan puanlama sistemi ile not ölçeklerinin bir zaman serisi verisine dönüșmesi mümkün olmaktadır.

Kapsamlı derecelendirme notları analize dâhil edilirken, söz konusu notlardaki günlük değișimler dikkate alınmaktadır. Fakat derecelendirme notlarına ilișkin veriler günlük olmadığından, öncelikle bu verilerin günlük verilere dönüștürülmesi gerekmektedir. Bu amaçla izlenen yol, not değișimi olana kadar ki tarih aralığında, kapsamlı derecelendirme notunun tekrar ettiği varsayımıdır. Örneğin, 3 Nisan 2008 tarihinde Standard \& Poor's Rating Services tarafından Türkiye'ye verilen kapsamlı derecelendirme notu 10,5 puana tekabül etmektedir. 3 Nisan 2008 tarihinden 18 Eylül 2009 tarihine kadar bir not değișimi olmamıștır. 18 Eylül 2009 tarihinde ise kapsamlı derecelendirme notu 11 puana yükselmektedir. 3 Nisan 2008 tarihi ile 18 Eylül 2009 tarihi arasında bir not değișimi olmadığından, bu tarih aralığındaki her gün için Standard \& Poor's Rating Services kapsamlı derecelendirme notu 10,5 puan olarak kabul edilmektedir. Bu șekilde kapsamlı derecelendirme notlarının günlük veriye dönüștürülmesi mümkün olmakta ve notlardaki günlük değișim hesaplanabilmektedir. Günlük değișimler ise her güne ait veriden önceki günün verisi çıkarılarak bulunmaktadır. 
Analizde kullanmakta olduğumuz bağımsız değișkenler ise Türkiye'de ve dünyada ortaya çıkan ekonomik, siyasi ve sosyal olayların çeșitli açılardan kategorik bir sınıflandırmaya tabi tutulmasıyla olușturulan değișkenlerdir. Türkiye'de ve dünyada ortaya çıkan önemli olayların belirlenmesi amacıyla yapılan taramalarda yılsonlarında yayımlanan almanaklardan ve gazete arșivlerinden faydalanılmıștır. Tarama neticesinde, araștırma döneminde bağımlı değișkenler üzerinde etkisi olduğu düșünülün 127 olaya ulașılmıștır. Tespit edilen olaylar kendi içerisinde bir sınıflandırmaya tabi tutulduğunda, ulașılan sonuçlar Tablo 5'te yer almaktadır.

Tablo 5. Türkiye ve Dünyada Orłaya Çıkan Ekonomik, Siyasi ve Sosyal Gelișmelerin Yer Aldığı Olaylara Ilișkin Sınıflandırma

\begin{tabular}{|c|l|c|}
\hline Olay Sıra & Olay Türü & Olay Sayısı \\
\hline X1 & İyi Olay & 87 \\
\hline X2 & Kötü Olay & 40 \\
\hline X3 & Siyasi Olay & 48 \\
\hline X4 & Ekonomik Olay & 79 \\
\hline X5 & Yurt Ị̇i İyi Olay & 44 \\
\hline X6 & Yurt Dıșı İyi Olay & 43 \\
\hline X7 & Yurt İçi Kötü Olay & 26 \\
\hline X8 & Yurt Dıșı Kötü Olay & 14 \\
\hline
\end{tabular}

Kaynak: Tarama neticesinde ulașılan olaylar değerlendirilerek tarafımızca olușturulmuștur.

Iyi olay olarak değerlendirilebilecek olaylara, fasılların $A B$ ile fiili müzakerelere açılması, Merkez Bankası́nın faiz oranlarında indirim kararları, FED'in faiz oranlarında indirim kararları, genel ve mahalli idare seçimleri, derecelendirme notu görünüm ve izlem artıșları örnek gösterilebilir. Kötü olay olarak değerlendirilebilecek olaylara ise, suikastler, ekonomik kriz neticesinde ortaya çıkan iflas kararları, Merkez Bankası'nın ve FED'in faiz oranlarında artıș kararları, sınır ötesi askeri operasyonlar, çeșitli davalar, yolsuzluk operasyonları, komșu ülkelere askeri müdahaleler, derecelendirme notu, görünüm ve izlem düșüșleri örnek gösterilebilir. 
İyi ve kötü olaylar da kendi içerisinde yurt içi-yurt dıșı kaynakIı olmalarına ve siyasi-ekonomik özellik tașımalarına göre ayrılmıștır. Örneğin, fasılların AB ile fiili müzakerelere açılması, suikastler, genel ve mahalli idare seçimleri, sını ötesi askeri operasyonlar, çeșitli davalar siyasi olay olarak değerlendirilirken; Merkez Bankası ve FED'in faiz oranlarındaki değișim kararları, derecelendirme notu, görünüm ve izlem değișiklikleri ekonomik olay olarak değerlendirilmiștir.

Kategorik sınıflandırmaya tabi tutulan olayların analize dâhil edilmesinde ise, olayın meydana geldiği tarihler 1, olay meydana gelmeyen tarihler ise 0 olarak kodlanmaktadır. Örneğin, 19 Ocak 2007 tarihinde Hrant Dink suikasti meydana gelmiștir. 21 Șubat 2007 tarihinde ise mortgage yasa tasarısı olarak adlandırılan kanun teklifi TBMM'de kabul edilmiștir. İyi olay ya da kötü olay olarak değerlendirilebilecek her iki olay 1 ile kodlanmaktadır. ìki tarih arasında herhangi bir olay gerçekleșmediği düșünüldüğünde bu tarihlerdeki iyi olay ya da kötü olay kategorisinde tarihlerin karșısına 0 ile kodlama yapılmaktadır. Bu șekilde bir düzenleme neticesinde 8 ayrı kategoriye ait sınıflandırma yapılması mümkün olmaktadır. Bu durumda bağımsız değișken olarak değerlendirilecek kategorik değișkenlerin yani olayların bağımlı değișken üzerindeki etkinliği incelenebilmektedir.

\section{Yöntem}

Regresyon analizinde temel olarak, bağımlı değișken ya da değișkenler ile bağımsız değișken ya da değișkenler arasındaki ilișkinin matematiksel olarak incelenmesi ve ortaya çıkan ilișki düzeyinin yorumlanması amaçlanmaktadır.

Bu doğrultuda Büyüköztürk (2012)'e göre;

- Bir bağımlı değișken ile bir bağımsız değișken arasındaki ilișkinin incelenmesine basit regresyon analizi,

- Bir bağımlı değișken ile birden fazla bağımsız değișken arasındaki ilișkinin incelenmesine çoklu regresyon analizi, 
- Birden fazla bağımlı değișken ile birden fazla bağımsız değișken arasındaki ilișkinin incelenmesine ise çok değișkenli regresyon analizi adı verilmektedir.

Çoklu regresyon analizinde, bağımsız değișkenler tarafından bağımlı değișkende açıklanan toplam varyansın yorumlanmasına, istatistiksel olarak açıklanan varyansın ve bağımsız değișkenlerin anlamlı olup olmadığına, bağımsız değișkenler ile bağımlı değișkenler arasındaki ilișkinin yönüne ilișkin bilgilere sahip olmak mümkün olmaktadır (Büyüköztürk, 2012: 98). Bu bakımdan yapılan analizlerde bağımsız değișkenlerin bağımlı değișkenler üzerindeki etkisi en küçük kareler yöntemiyle çoklu doğrusal regresyon modeline göre incelenmektedir.

\section{Analiz ve Bulgular}

Bu kısımda yapılan analizlerle ilgili olarak öncelikle bağımlı ve bağımsız değișkenlere ilișkin tanımlayıcı istatistiklere yer verilmektedir. Değișkenlerle ilgili tanımlayıcı istatistikler Tablo 6'da yer almaktadır. 


\begin{tabular}{|c|c|c|c|c|c|c|c|c|c|c|c|c|}
\hline$\stackrel{\infty}{x}$ & o. & 웅 & $\underset{-}{\stackrel{0}{2}}$ & 8 & o. & $\stackrel{\text { 莒 }}{=}$ & $\frac{\stackrel{\sim}{2}}{\stackrel{f}{m}}$ & 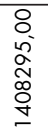 & 8 & $\begin{array}{l}8 \\
\text { ¿ }\end{array}$ & $\begin{array}{l}\circ \\
\stackrel{p}{p}\end{array}$ & $\stackrel{\circ}{\circ}$ \\
\hline$\vec{x}$ & $\begin{array}{l}\overline{0} \\
0\end{array}$ & 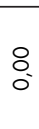 & $\underset{-}{8}$ & 8 & $\frac{\cong}{0}$ & 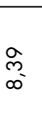 & 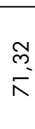 & $\begin{array}{l}\text { Oे } \\
\text { ले } \\
\text { o } \\
\text { ल } \\
\text { pे }\end{array}$ & 8 & $\begin{array}{l}\text { ৪ } \\
\text { ㅇ }\end{array}$ & $\begin{array}{l}n \\
\text { ñ } \\
\text { w }\end{array}$ & $\stackrel{\circ}{\circ}$ \\
\hline$\stackrel{2}{x}$ & õ & $\stackrel{8}{\circ}$ & $\stackrel{8}{-}$ & : & $\frac{n}{0}$ & $\overbrace{0}^{\text {g }}$ & 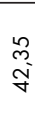 & 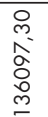 & 8 & 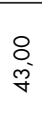 & 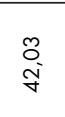 & $\stackrel{\circ}{\circ}$ \\
\hline$\ddot{x}$ & õ & 8 & $\underset{-}{8}$ & 8 & $\frac{n}{0}$ & $\underset{\substack{\sim \\
0 \\
0}}{ }$ & $\begin{array}{l}\stackrel{\infty}{m} \\
\stackrel{q}{q}\end{array}$ & 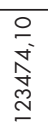 & 8 & $\begin{array}{l}8 \\
\text { ì }\end{array}$ & $\begin{array}{l}\stackrel{+}{\alpha} \\
\text { ণ্ }\end{array}$ & $\stackrel{\circ}{\circ}$ \\
\hline$\underset{x}{\nexists}$ & $\begin{array}{l}\text { O } \\
0\end{array}$ & \& & $\stackrel{8}{\stackrel{-}{-}}$ & 8 & ָ̊ & 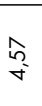 & $\stackrel{\infty}{i}$ & $\begin{array}{l}\text { Oे } \\
\text { ò } \\
\text { o } \\
\text { d }\end{array}$ & 8 & $\begin{array}{l}8 \\
\circ \\
\infty\end{array}$ & $\begin{array}{l}\text { J } \\
\text { o } \\
\delta^{\circ}\end{array}$ & $\stackrel{\circ}{\circ}$ \\
\hline$\widetilde{x}$ & ֶ̊: & 8 & $\underset{-}{8}$ & : & $\frac{0}{0}$ & $\begin{array}{l}0 \\
0 \\
0\end{array}$ & 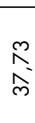 & 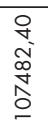 & 8 & $\begin{array}{l}\text { ৪ } \\
\text { o } \\
\text { o }\end{array}$ & $\begin{array}{l}\stackrel{a}{\hat{y}} \\
\text { b }\end{array}$ & ঃ요 \\
\hline$\widetilde{x}$ & $\begin{array}{l}\text { ô } \\
\text { o. }\end{array}$ & 8 & $\underset{-}{8}$ & 8 & $\frac{\Delta}{0}$ & $\begin{array}{l}\infty \\
0 \\
0 \\
0\end{array}$ & $\begin{array}{l}\hat{o} \\
\dot{v}\end{array}$ & $\begin{array}{l}0 \\
\circ \\
\circ \\
\circ \\
\infty \\
0 \\
0\end{array}$ & 8 & $\begin{array}{l}8 \\
\text { ¿ }\end{array}$ & $\frac{\circ}{\text { à }}$ & ঃ \\
\hline $\bar{x}$ & $\begin{array}{l}0 \\
0 \\
0\end{array}$ & 8 & $\underset{-}{\stackrel{-}{2}}$ & 8 & $\begin{array}{c}\bar{N} \\
0\end{array}$ & $\underset{m}{\stackrel{m}{\sim}}$ & $\hat{\alpha}$ & 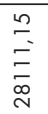 & 8 & $\begin{array}{l}\text { ৪ } \\
\infty \\
\infty \\
\infty\end{array}$ & $\begin{array}{l}\vec{d} \\
\underset{\infty}{\infty} \\
\infty\end{array}$ & ঃ \\
\hline $\begin{array}{l}\text { U } \\
\text { Ö } \\
\text { I } \\
\text { U⿱艹亡\zh22亡 }\end{array}$ & $\begin{array}{l}8 \\
0\end{array}$ & 8 & $\stackrel{n}{\stackrel{n}{=}}$ & $\begin{array}{l}\text { in } \\
\text { ô }\end{array}$ & 号 & 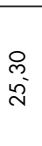 & $\begin{array}{l}\text { N } \\
- \\
0 \\
\infty \\
\infty\end{array}$ & 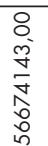 & 8 & $\stackrel{\circ}{\stackrel{n}{N}}$ & $\underset{\substack{\infty \\
\forall}}{\stackrel{0}{*}}$ & ঃ요 \\
\hline 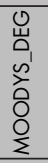 & 8 & 8 & $\stackrel{8}{=}$ & $\begin{array}{l}\text { ôn } \\
\text { ô }\end{array}$ & \%̊ & $\stackrel{\nwarrow}{\AA}$ & $\begin{array}{l}\infty \\
\infty \\
\tilde{N} \\
\sigma \\
\sigma\end{array}$ & $\begin{array}{l}8 \\
8 \\
0 \\
2 \\
\hat{2} \\
\frac{1}{2} \\
\frac{1}{2}\end{array}$ & 8 & $\stackrel{\circ}{\sim}$ & $\stackrel{\sim}{\sim}$ & ঃ \\
\hline $\begin{array}{l}\text { U } \\
\text { Oे } \\
\text { ळे } \\
心\end{array}$ & 8 & \& & $\stackrel{\text { in }}{=}$ & $\begin{array}{l}\text { 号 } \\
\text { ô }\end{array}$ & ֶ̊ & $\begin{array}{l}\bar{n} \\
\text { ¿े }\end{array}$ & $\begin{array}{l}= \\
= \\
0 \\
0\end{array}$ & 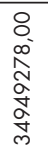 & 8 & $\stackrel{\circ}{\sim}$ & $\underset{\sim}{\stackrel{\sim}{\sim}}$ & ঃ \\
\hline $\begin{array}{l}0 \\
\text { 岁 } \\
u \\
0\end{array}$ & $\begin{array}{l}\widetilde{\delta} \\
\text { Oे }\end{array}$ & $\frac{0}{i}$ & $\begin{array}{l}n \\
o \\
o \\
\underline{m}\end{array}$ & $\frac{\sigma}{\tilde{N}}$ & 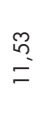 & $\begin{array}{l}\widetilde{n} \\
\text { ?. }\end{array}$ & $\begin{array}{l}\text { N } \\
\text { Dे }\end{array}$ & 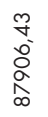 & 8 & $\begin{array}{l}\text { ৪ } \\
\text { ò }\end{array}$ & 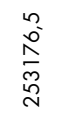 & ঃ \\
\hline & 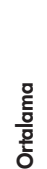 & 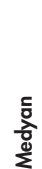 & 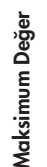 & 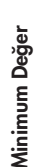 & 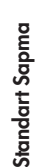 & 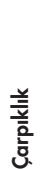 & $\begin{array}{l}\text { 恙 } \\
\text { 产 }\end{array}$ & 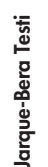 & $\begin{array}{l}\underline{\underline{\underline{D}}} \\
\frac{\overline{\bar{b}}}{0}\end{array}$ & : & 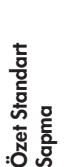 & 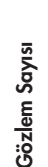 \\
\hline
\end{tabular}


Bağımlı değișkenlerle ilgili olarak günlük veriler kullanıldığından, analiz döneminde 1906 gözlem sonucuna ulașılmaktadır. Gözlem sonuçları, bağımlı değișkende bir önceki güne göre ortaya çıkan değișmeyi ifade etmektedir. Bu bağlamda, CDS primlerinde ortalama değișim yaklașık yüzde 2 düzeyindeyken, Standard \& Poor's Rating, Moody's Corporation ve Fitch Ratings kapsamlı derecelendirme notlarındaki değișim sıfıra yakın seyretmektedir.

Tablo 6'da yer alan veriler, araștırma dönemi içerisinde, CDS primlerindeki en yüksek değișimlerin, 131 puan artıș ve 122 puan düșüș șeklinde gerçekleștiğini göstermektedir. Derecelendirme notlarına ilișkin veriler incelendiğinde ise, Standard \& Poor's Rating Services kapsamlı derecelendirme notlarındaki en yüksek artıșın 1,5 puan, en yüksek düșüșün 0,5 puan ile; Moody's Corporation kapsamlı derecelendirme notlarındaki en yüksek artıșın 1 puan, en yüksek düșüșün 0,5 puan ile; Fitch Ratings kapsamlı derecelendirme notlarındaki en yüksek artıșın 1,75 puan, en yüksek düșüșün 0,5 puan ile gerçekleștiği görülmektedir.

Bağımlı değișkenlerdeki değișimlerin daha net görülebilmesi için șekillerinin çizilmesi faydalı olacaktır. Bu kapsamda bağımlı değișkenlerden ilki olan CDS primlerindeki günlük değișimlere ilișkin veriler Șekil 1'de yer almaktadır.

\section{Șekil 1. CDS Primlerindeki Günlük Değișim}

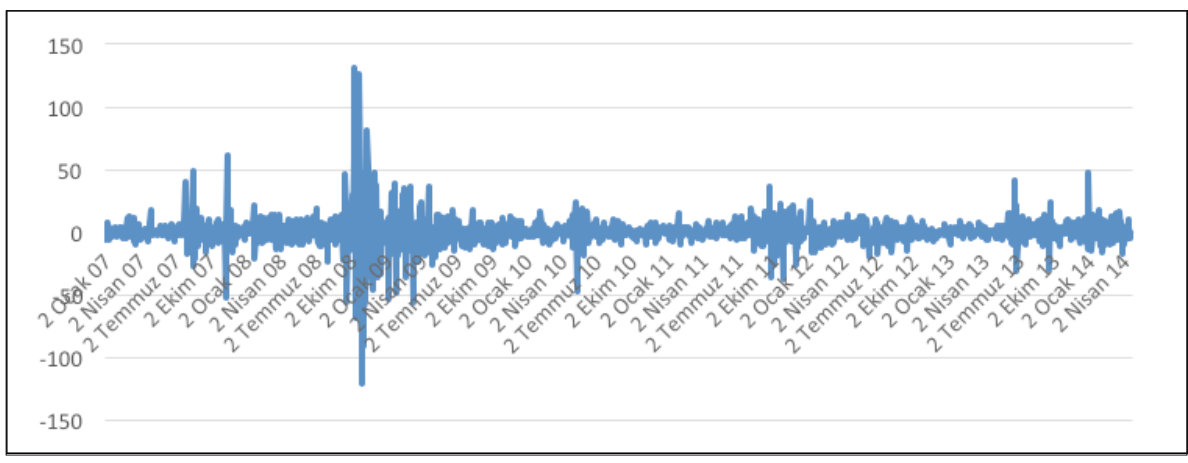

Șekil 1'de görülebileceği üzere, CDS primlerindeki pozitif değișimin yani CDS puanlarında bir önceki güne göre artıșın en yüksek olduğu dönemler Eylül, Ekim, Kasım 2008 dönemleridir. 
CDS primlerindeki negatif değișimin yani CDS puanlarında bir önceki güne göre düșüssün en yüksek olduğu dönemler ise yine Eylül, Ekim, Kasım 2008 dönemleridir. Bu dönemlerde CDS primlerindeki günlük değișim, yaklașık 125 puan civarındadır. 2007 yılı Eylül ayı, 2008 yılı Ocak ayı, 2009 yılı Ocak ve Mayıs ayları, 2010 yılı Temmuz ayı, 2012 yılı Ocak ayı, 2013 yılı Eylül ve Ekim ayları ve 2014 yılı Nisan ayında da CDS primlerinin günlük değișiminde 2008 yılı Eylül, Ekim ve Kasım aylarına nazaran daha küçük çaplı fakat belirgin sıçramalar dikkat çekmektedir.

Bağımlı değișkenlerden bir diğeri olan Standard \& Poor's Rating Services kapsamlı derecelendirme notlarına ilișkin değișimler Șekil 2'de yer almaktadır.

Șekil 2. Standard \& Poors Rating Services Kapsamlı Derecelendirme Notları Günlük Değișim

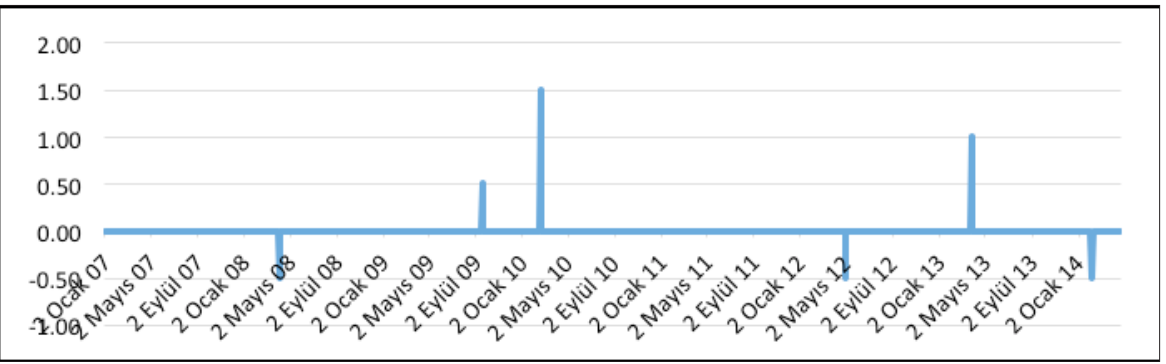

Standard \& Poor's Rating Services kapsamlı derecelendirme notları, analiz dönemi içerisinde yalnızca 6 defa (üçü görünüm düșüșü, üçü not ve görünüm artıșı șeklinde) değișime uğramıștır. Bunlardan üçü kapsamlı derecelendirme notu artıșı, diğer üçü ise not azalıșı șeklinde gerçekleșmiștir. Not artıșının en yüksek olduğu dönem Șubat 2010'a isabet etmekle birlikte, araștırma dönemi içerisinde not değișiminin sadece 6 defa olması kapsamlı derecelendirme notlarındaki değișime ilișkin serinin büyük kısmında değișimin sıfıra denk gelmesine neden olmaktadır.

Șekil 3'te ise Moody's Corporation kapsamlı derecelendirme notlarının araștırma dönemi içerisindeki değișimi yer almaktadır. Șekil 2'de olduğu gibi Șekil 3'te de kapsamlı derecelendirme notlarında yalnızca 6 değișim (biri görünüm düșüșü, beși not ve gö- 
rünüm artıșı șeklinde) meydana gelmiștir. Bu değișimler içerisinde en dikkat çekeni ise Haziran 2012'de gerçekleșen not artıșıdır. Araștırma dönemi içerisinde not değișiminin yalnızca 6 defa olması, günlük ortalama not değișimlerinin sıfır olarak gerçekleșmesine neden olmaktadır.

Șekil 3. Moody's Corporation Kapsamlı Derecelendirme Notları Günlük Değișim

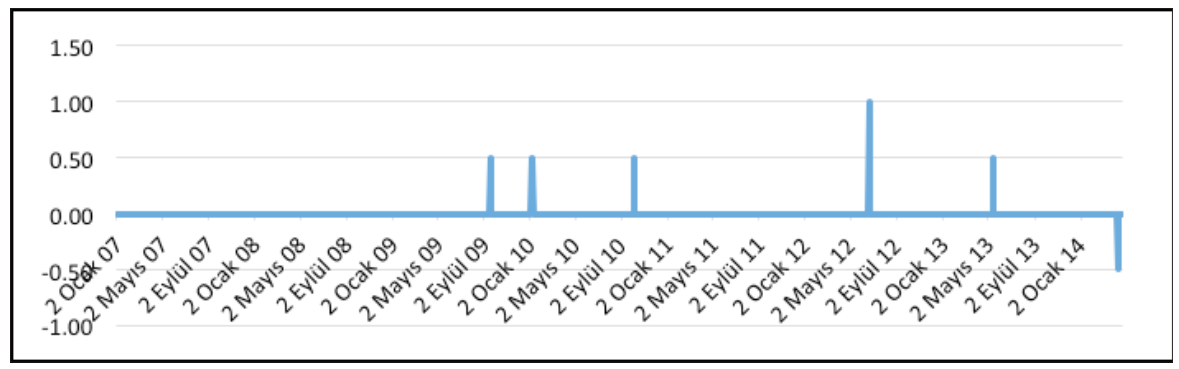

Diğer bir derecelendirme kurulușu olan Fitch Ratings kapsamlı derecelendirme notlarındaki değișim ise Șekil 4 'te yer almaktadır. Diğer derecelendirme șirketlerinde olduğu gibi, Fitch Rating kapsamlı derecelendirme notları da araștırma döneminde 6 kez (ikisi görünüm düșüșü, dördü not ve görünüm artıșı șeklinde) değișikliğe uğramıștır. Bu değișimlerden en dikkat çekicisi, Aralık 2009'da gerçekleșmiștir. Not değișimlerinin bu kadar az olması günlük kapsamlı derecelendirme notlarındaki değișimin sıfır olmasına neden olan önemli bir husus olarak karșımıza çıkmaktadır.

Șekil 4. Fitch Ratings Kapsamlı Derecelendirme Notları Günlük Değișim

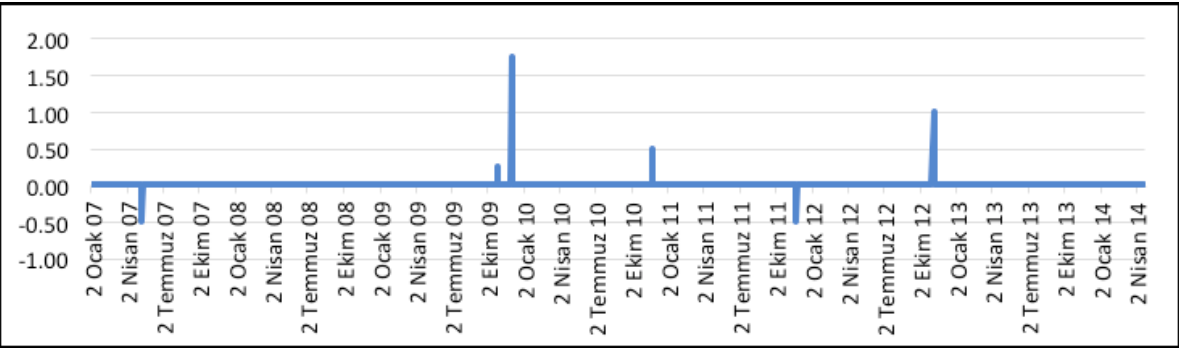


Yapılan analizler doğrultusunda, bağımlı değișkenler ile bağımsız değișkenler arasındaki ilișkinin ortaya koyulması amacıyla olușturulan çoklu doğrusal regresyon modellerine ilișkin elde edilen sonuçlar Tablo 7'de yer almaktadır.

Bağımlı değișkenler ile bağımsız değișkenler arasındaki ilișkinin incelenmesi amacıyla 20 farklı model olușturulmuș olup, bu modellerin ilk dördünde iyi ve kötü olayların bağımlı değișkenler üzerindeki etkisi incelenmektedir. Bu amaçla olușturulan modeller așağıda sıralanmaktadır.

$$
\begin{aligned}
& \mathrm{CDS}_{\mathrm{DEG}}=0,09-3,59 * X_{1}+4,26 * X_{2} \\
& \mathrm{~S} \& \mathrm{P}_{\mathrm{DEG}}=0,03 * X_{1}-0,04 * X_{2} \\
& \mathrm{MOODYS}_{\mathrm{DEG}}=0,03 * X_{1}-0,01 * X_{2} \\
& \mathrm{FITCH}_{\mathrm{DEG}}=0,04 * X_{1}-0,03 * X_{2}
\end{aligned}
$$

1, 2, 3 ve 4 numaralı modellere ilișkin teorik beklenti, iyi olayların CDS primlerini düșürmesi ve derecelendirme notlarını artırması iken kötü olayların ise CDS primlerini yükseltmesi ve derecelendirme notlarını düșürmesidir. Elde edilen sonuçlar, teorik beklentiyi istatistiksel olarak anlamlı bir biçimde desteklemektedir. Bir karșılaștırma yapıldığında ise, CDS primleri üzerinde bu etkinin diğer değișkenlere göre daha fazla olduğu tespit edilmiștir. 
Tablo 7. Olușturulan Modellere Iliș̦in Çoklu Doğrusal Regresyon Sonuçları

\begin{tabular}{|c|c|c|c|c|c|c|c|c|c|c|}
\hline & $\begin{array}{l}\text { Bağımlı } \\
\text { Değișken }\end{array}$ & $\begin{array}{l}\text { Bağımsız } \\
\text { Değișken }\end{array}$ & Katsayı & $\begin{array}{c}\text { Standart } \\
\text { Hata }\end{array}$ & $\underset{\text { İstatistiği }}{T}$ & $\begin{array}{c}\text { T } \\
\text { İstatistiği } \\
\text { Olasilık }\end{array}$ & $\mathbf{R}^{2}$ & $\begin{array}{c}\text { Durbin } \\
\text { Watson }\end{array}$ & $\underset{\text { İstatistiği }}{\mathbf{F}}$ & $\begin{array}{c}\text { F } \\
\text { İstatistiği } \\
\text { Olasilık }\end{array}$ \\
\hline \multirow{3}{*}{ Model 1} & \multirow{3}{*}{ CDS_DEG } & C & 0,09 & 0,27 & 0,34 & 0,73 & \multirow{3}{*}{0,01} & \multirow{3}{*}{1,63} & \multirow{3}{*}{6,92} & \multirow{3}{*}{0,00} \\
\hline & & $X 1$ & $-3,59$ & 1,26 & $-2,84$ & 0,00 & & & & \\
\hline & & $x 2$ & 4,26 & 1,84 & 2,31 & 0,02 & & & & \\
\hline \multirow{2}{*}{ Model 2} & \multirow{2}{*}{ S\&P_DEG } & $\mathrm{X} 1$ & 0,03 & 0,01 & 6,94 & 0,00 & \multirow{2}{*}{0,04} & \multirow{2}{*}{2,01} & \multirow{2}{*}{-} & \multirow{2}{*}{ - } \\
\hline & & $\mathrm{X} 2$ & $-0,04$ & 0,01 & $-5,12$ & 0,00 & & & & \\
\hline \multirow{2}{*}{ Model 3} & \multirow{2}{*}{$\begin{array}{l}\text { MOODYS } \\
\text { DEG }\end{array}$} & $\mathrm{X} 1$ & 0,03 & 0,00 & 9,59 & 0,00 & \multirow{2}{*}{0,05} & \multirow{2}{*}{2,01} & \multirow[b]{2}{*}{ - } & \multirow[b]{2}{*}{ - } \\
\hline & & $\times 2$ & $-0,01$ & 0,01 & $-2,36$ & 0,02 & & & & \\
\hline \multirow{2}{*}{ Model 4} & \multirow{2}{*}{ FITCH_DEG } & $\mathrm{X} 1$ & 0,04 & 0,01 & 7,54 & 0,00 & \multirow{2}{*}{0,03} & \multirow{2}{*}{2,00} & \multirow[b]{2}{*}{-} & \multirow{2}{*}{ - } \\
\hline & & $\mathrm{X} 2$ & $-0,03$ & 0,01 & $-3,18$ & 0,00 & & & & \\
\hline \multirow{3}{*}{ Model 5} & & $C$ & 0,19 & 0,27 & 0,69 & 0,49 & & & & \\
\hline & CDS_DEG & $x 1 * x 3$ & $-2,96$ & 2,28 & $-1,30$ & 0,19 & 0,01 & 1,63 & 4,31 & 0,01 \\
\hline & & $x 1 * x 4$ & $-3,99$ & 1,50 & $-2,66$ & 0,01 & & & & \\
\hline & & $C$ & $-0,00$ & 0,00 & $-0,76$ & 0,45 & & & & \\
\hline Model 6 & S\&P_DEG & $x 1 * x 3$ & 0,00 & 0,01 & 0,09 & 0,93 & 0,03 & 2,01 & 34,23 & 0,00 \\
\hline & & $\mathrm{X} 1 * x 4$ & 0,05 & 0,01 & 8,27 & 0,00 & & & & \\
\hline & & $C$ & $-0,00$ & 0,00 & $-0,35$ & 0,72 & & & & \\
\hline Model 7 & $\begin{array}{l}\text { MOODYS } \\
\text { DEG }\end{array}$ & $x 1 * x 3$ & 0,00 & 0,01 & 0,04 & 0,97 & 0,06 & 2,02 & 65,32 & 0,00 \\
\hline & & $\mathrm{X} 1 * \times 4$ & 0,05 & 0,00 & 11,43 & 0,00 & & & & \\
\hline & & C & $-0,00$ & 0,00 & $-0,47$ & 0,64 & & & & \\
\hline Model 8 & FITCH_DEG & $x 1 * x 3$ & 0,00 & 0,01 & 0,06 & 0,96 & 0,04 & 2,00 & 40,31 & 0,00 \\
\hline & & $\mathrm{X} 1 * \times 4$ & 0,06 & 0,01 & 8,98 & 0,00 & & & & \\
\hline & & $C$ & $-0,07$ & 0,27 & $-0,28$ & 0,78 & & & & \\
\hline Model 9 & CDS_DEG & $x 2 * x 3$ & 6,21 & 2,47 & 2,51 & 0,01 & 0,00 & 1,63 & 3,47 & 0,03 \\
\hline & & $X 2 * x 4$ & 2,24 & 2,73 & 0,82 & 0,41 & & & & \\
\hline & & $C$ & 0,00 & 0,00 & 1,49 & 0,14 & & & & \\
\hline Model 10 & S\&P_DEG & $x 2 * x 3$ & $-0,00$ & 0,01 & $-0,16$ & 0,87 & 0,03 & 2,00 & 29,69 & 0,00 \\
\hline & & $x 2 * \times 4$ & $-0,08$ & 0,01 & $-7,71$ & 0,00 & & & & \\
\hline & & $C$ & 0,00 & 0,00 & 2,03 & 0,04 & & & & \\
\hline Model 11 & $\begin{array}{l}\text { MOODYS } \\
\text { DEG }\end{array}$ & $x 2 * x 3$ & $-0,00$ & 0,01 & $-0,22$ & 0,83 & 0,01 & 2,00 & 6,58 & 0,00 \\
\hline & & $\mathrm{X} 2 * \times 4$ & $-0,03$ & 0,01 & $-3,62$ & 0,00 & & & & \\
\hline & & C & 0,00 & 0,00 & 1,61 & 0,11 & & & & \\
\hline Model 12 & FITCH_DEG & $x 2 * x 3$ & $-0,00$ & 0,01 & $-0,17$ & 0,86 & 0,01 & 2,00 & 11,63 & 0,00 \\
\hline & & $x 2 * \times 4$ & $-0,06$ & 0,01 & $-4,82$ & 0,00 & & & & \\
\hline & & $C$ & 0,19 & 0,27 & 0,69 & 0,49 & & & & \\
\hline Model 13 & CDS_DEG & $\times 5$ & $-1,78$ & 1,76 & $-1,01$ & 0,31 & 0,01 & 1,63 & 5,46 & 0,00 \\
\hline & & X6 & $-5,63$ & 1,78 & $-3,17$ & 0,00 & & & & \\
\hline
\end{tabular}




\begin{tabular}{|c|c|c|c|c|c|c|c|c|c|c|}
\hline \multirow{3}{*}{ Model 14} & \multirow{3}{*}{ S\&P_DEG } & $C$ & $-0,00$ & 0,00 & $-0,76$ & 0,45 & \multirow{3}{*}{0,05} & \multirow{3}{*}{2,00} & \multirow{3}{*}{49,29} & \multirow{3}{*}{0,00} \\
\hline & & X5 & 0,00 & 0,01 & 0,12 & 0,91 & & & & \\
\hline & & X6 & 0,07 & 0,01 & 9,93 & 0,00 & & & & \\
\hline \multirow{3}{*}{ Model 15} & \multirow{3}{*}{$\begin{array}{l}\text { MOODYS } \\
\text { DEG }\end{array}$} & C & $-0,00$ & 0,00 & $-0,35$ & 0,73 & \multirow{3}{*}{0,05} & \multirow{3}{*}{2,01} & \multirow{3}{*}{50,18} & \multirow{3}{*}{0,00} \\
\hline & & x5 & 0,02 & 0,01 & 4,50 & 0,00 & & & & \\
\hline & & X6 & 0,05 & 0,01 & 9,05 & 0,00 & & & & \\
\hline \multirow{3}{*}{ Model 16} & \multirow{3}{*}{ FITCH_DEG } & $C$ & $-0,00$ & 0,00 & $-0,48$ & 0,63 & \multirow{3}{*}{0,06} & \multirow{3}{*}{2,00} & \multirow{3}{*}{58,46} & \multirow{3}{*}{0,00} \\
\hline & & X5 & 0,00 & 0,01 & 0,07 & 0,94 & & & & \\
\hline & & X6 & 0,08 & 0,01 & 10,81 & 0,00 & & & & \\
\hline \multirow{3}{*}{ Model 17} & \multirow{3}{*}{ CDS_DEG } & $C$ & $-0,07$ & 0,27 & $-0,28$ & 0,78 & \multirow{3}{*}{0,00} & \multirow{3}{*}{1,63} & \multirow{3}{*}{3,30} & \multirow{3}{*}{0,04} \\
\hline & & $x 7$ & 5,65 & 2,28 & 2,48 & 0,01 & & & & \\
\hline & & $x 8$ & 2,15 & 3,09 & 0,69 & 0,49 & & & & \\
\hline \multirow{3}{*}{ Model 18} & \multirow{3}{*}{ S\&P_DEG } & C & 0,00 & 0,00 & 1,48 & 0,14 & \multirow{3}{*}{0,02} & \multirow{3}{*}{2,00} & \multirow{3}{*}{19,34} & \multirow{3}{*}{0,00} \\
\hline & & $x 7$ & $-0,02$ & 0,01 & $-2,26$ & 0,02 & & & & \\
\hline & & $\mathrm{x} 8$ & $-0,07$ & 0,01 & $-5,82$ & 0,00 & & & & \\
\hline \multirow{3}{*}{ Model 19} & \multirow{3}{*}{$\begin{array}{l}\text { MOODYS } \\
\text { DEG }\end{array}$} & C & 0,00 & 0,00 & 2,03 & 0,04 & \multirow{3}{*}{0,01} & & & \\
\hline & & $x 7$ & $-0,00$ & 0,01 & $-0,24$ & 0,81 & & 2,00 & 8,28 & 0,00 \\
\hline & & $x 8$ & $-0,04$ & 0,01 & $-4,07$ & 0,00 & & & & \\
\hline & & $C$ & 0,00 & 0,00 & 1,61 & 0,11 & & & & \\
\hline Model 20 & FITCH_DEG & $x 7$ & $-0,02$ & 0,01 & $-2,12$ & 0,03 & 0,01 & 2,00 & 6,04 & 0,00 \\
\hline & & X8 & $-0,04$ & 0,01 & $-2,78$ & 0,01 & & & & \\
\hline
\end{tabular}

Olușturulan diğer bir grup modelde ise, iyi siyasi ve iyi ekonomik olayların bağımlı değișkenler üzerindeki etkisi test edilmektedir. Bu doğrultuda olușturulan modeller ve sonuçları așağıda gösterilmektedir.

$$
\begin{aligned}
& \mathrm{CDS}_{\mathrm{DEG}}=0,19-2,96 * X_{1}{ }^{*} X_{3}-3,99 * X_{1} * X_{4} \\
& {\mathrm{~S} \& P_{D E G}}_{D=}-0,00+0,00 * X_{1}{ }^{*} X_{3}+0,05 * X_{1}{ }^{*} X_{4} \\
& M O O D Y S_{D E G}=-0,00+0,00 * X_{1} * X_{3}+0,05 * X_{1}{ }^{*} X_{4} \\
& \mathrm{FITCH}_{\mathrm{DEG}}=-0,00+0,00 * X_{1} * X_{3}+0,06 * X_{1}{ }^{*} X_{4}
\end{aligned}
$$

Ulașılan sonuçlara göre, iyi ekonomik olayların bağımlı değișkenler üzerinde etkili olduğu, bașka bir ifadeyle, CDS primlerini azalttığı ve derecelendirme notlarını artırdığı; iyi siyasi olayların ise bağımlı değișkenleri etkilemediği tespit edilmiștir.

Kötü siyasi ve ekonomik olayların bağımlı değișkenler üzerindeki etkileri ise așağıdaki modeller ile test edilmiștir. 


$$
\begin{aligned}
& \operatorname{CDS}_{D E G}=-0,07+6,21 * X_{2}{ }^{*} X_{3}+2,24 * X_{2}{ }^{*} X_{4} \\
& S_{P_{D E G}}=0,00-0,00 * X_{2}{ }^{*} X_{3}-0,08 * X_{2}{ }^{*} X_{4} \\
& M O O D Y S_{D E G}=0,00-0,00 * X_{2}{ }^{*} X_{3}-0,03 * X_{2}{ }^{*} X_{4} \\
& \text { FITCH }_{D E G}=0,00-0,00 * X_{2}{ }^{*} X_{3}-0,06 * X_{2}{ }^{*} X_{4}
\end{aligned}
$$

$9,10,11$ ve 12 numaralı modellerden elde edilen sonuçlar, kötü siyasi olayların CDS primleri dıșındaki bağımlı değișkenler üzerinde istatistiksel olarak anlamlı bir etkisi olmadığını; kötü ekonomik olayların ise CDS primleri dıșındaki bağımlı değișkenleri etkilediğini göstermektedir. CDS primleri üzerindeki etki, teorik beklentiyle uyumlu olarak CDS primlerinde yükseliș; derecelendirme notları üzerindeki etki ise, teorik beklentiyle uyumlu olarak derecelendirme notlarında düșüș olarak ortaya çıkmaktadır.

lyyi olay kaynaklarının yurt içi ve yurt dıșı olması durumunda ortaya çıkan sonuçlar ise așağıdaki modellerde yer almaktadır.

$$
\begin{aligned}
& C_{D S} S_{D E G}=0,19-1,78 * X_{5}-5,63 * X_{6} \\
& S \& P_{D E G}=-0,00+0,00 * X_{5}+0,07 * X_{6} \\
& M O O D Y S_{D E G}=-0,00+0,02 * X_{5}+0,05 * X_{6} \\
& \text { FITCH }_{D E G}=-0,00+0,00 * X_{5}+0,08 * X_{6}
\end{aligned}
$$

Elde edilen sonuçlar, yurt içi kaynaklı iyi olayların Moody's derecelendirme notları haricindeki bağımlı değișkenler üzerinde anlamlı bir etkisi olmadığını göstermektedir. Yurt dıșı kaynaklı iyi olaylar ise, Moody's derecelendirme notları haricindeki bağımlı değișkenler üzerinde teorik beklentiyle uyumlu etkiler olușmaktadır.

Yurt içi ve yurt dıșı kaynaklı kötü olayların bağımlı değișkenler üzerindeki etkisi ise așağıdaki modellerde yer almaktadır.

$$
\begin{aligned}
& \operatorname{CDS}_{\mathrm{DEG}}=-0,07+5,65 * X_{7}+2,15 * X_{8} \\
& S \& P_{D E G}=0,00-0,02 * X_{7}-0,07 * X_{8} \\
& M O O D Y S_{D E G}=0,00-0,00 * X_{7}-0,04 * X_{8}
\end{aligned}
$$




$$
\mathrm{FITCH}_{\mathrm{DEG}}=0,00-0,02 * X_{7}-0,04 * X_{8}
$$

Yurt dıșı kaynaklı kötü olayların CDS primleri ve Standard \& Poor's derecelendirme notları üzerinde istatistiksel olarak anlamlı bir etkisi bulunmazken, yurt içi kaynaklı kötü olayların ise Moody's derecelendirme notları üzerinde bir etkisi bulunmamaktadır. Yurt içi kaynaklı kötü olaylar, CDS primlerini teorik beklenti dâhilinde artııırken, derecelendirme notlarını düșürmektedir. Yurt dıșı kaynaklı kötü olaylar ise yalnızca Moody's ve Fitch derecelendirme notlarını teorik beklenti dâhilinde düșürmektedir.

Bağımsız değișkenlerin bağımlı değișkenler üzerinde bir etkisi olup olmadığını ve etkinin varlığı durumunda bağımlı değișkenin yönünün ne olduğunu bir bütün halinde görmek amacıyla Tablo 8'de yer alan veriler incelendiğinde, 10 kategorik olay grubunun, bağımlı değișkenler üzerindeki etki sayılarının birbirine yakın olduğu görülmektedir. Bașka bir ifadeyle, CDS primleri üzerinde anlamlı etkiye sahip olan olay sayısı 6 iken, derecelendirme notları üzerinde anlamlı etkiye sahip olan olay sayısı 7'dir. Bu doğrultuda anlamsız etkiye sahip olay sayısı, CDS primleri için 4, derecelendirme notları için ise 3 olarak belirlenmiștir.

Araștırma neticesinde,

- iyi ve kötü olay olarak değerlendirilen olayların tüm bağımlı değișkenler üzerinde istatistiksel olarak anlamlı bir etkisinin olduğu

- iyi siyasi olayların hiçbir değișken üzerinde anlamlı bir etkisinin olmadığı

- iyi ekonomik olayların tüm bağımlı değișkenler üzerinde anlamlı bir etkisinin olduğu

- kötü siyasi olayların yalnızca CDS primleri üzerinde anlamlı bir etkisinin olduğu

- kötü ekonomik olayların ise yalnızca CDS primleri üzerinde anlamlı bir etkisinin olmadığı tespit edilmiștir. 


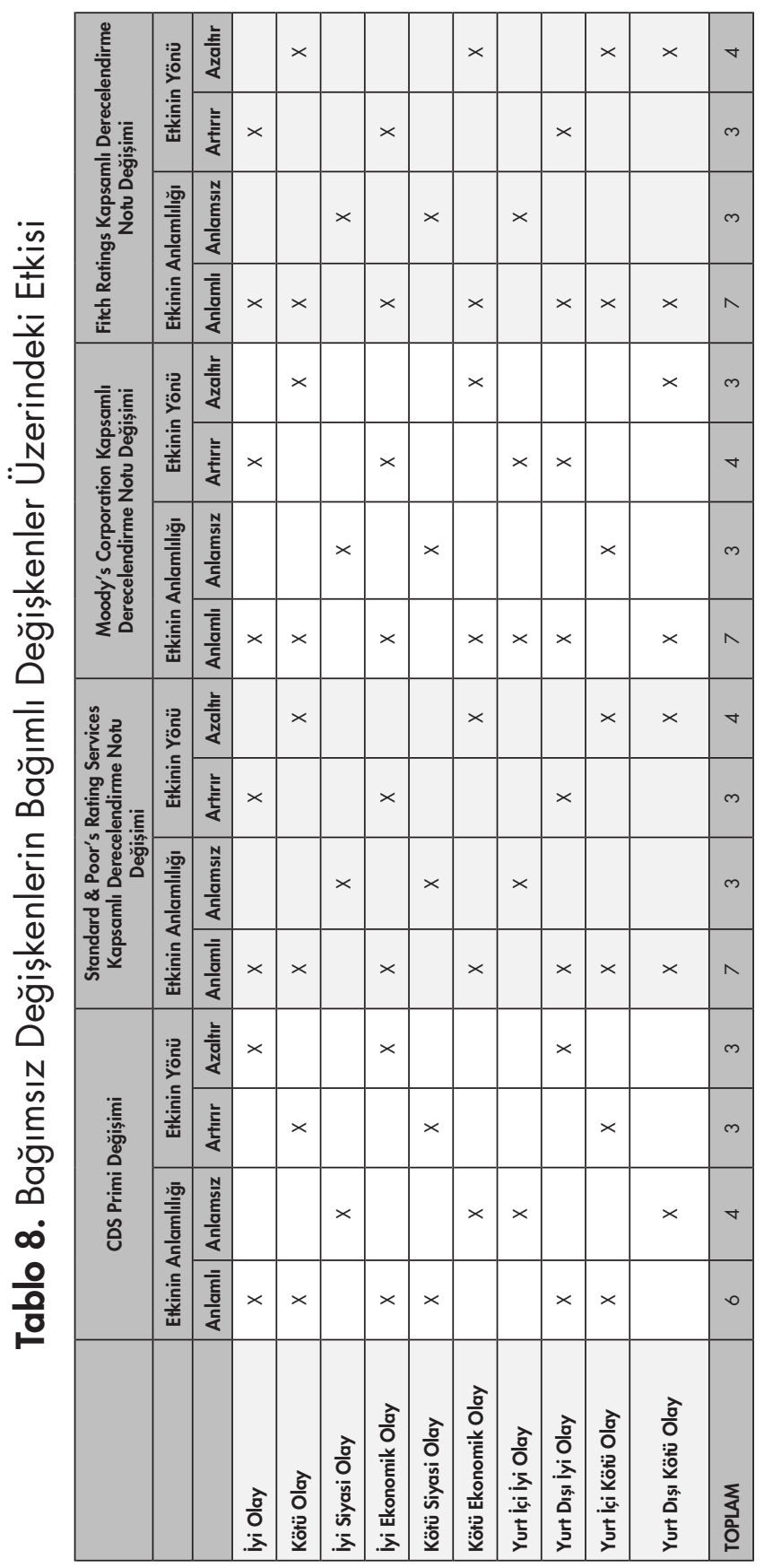


Olayların çıkıș noktası ile ilgili bir değerlendirme yapıldığında ise,

- yurt içi kaynaklı iyi olayların Moody's haricinde bağımlı değișkenler üzerinde bir etkisi olmadığı

- yurt içi kaynaklı kötü olayların sadece Moody's üzerinde etkisi olmadığı

- yurt dıșı kaynaklı iyi olayların tüm değișkenler üzerinde anlamlı bir etki gösterdiği

- yurt dıșı kaynaklı kötü olayların ise yalnızca CDS primleri üzerinde anlamlı bir etkisinin olmadığı belirlenmiștir.

\section{Sonuç}

Kredi değerliliğinin ve ülke riskliliğinin belirlenmesinde kullanılan en temel gösterge, derecelendirme notlarıdır. Fakat son dönemde, özellikle ortaya çıkan olayların etkisinin hemen yansıtılması bașta olmak üzere, çok çeșitli açılardan derecelendirme notları eleștirilere maruz kalmaktadır. Bu süreçte derecelendirme notlarına ilișkin alternatif arayıșları dikkatleri CDS primlerine yöneltmektedir. Bu açıdan derecelendirme notları ve CDS primlerinin Türkiye ölçeğinde ortaya çıkan ya da Türkiye'yi etkileyen olaylara verdiği tepkilerin ve bu olayların derecelendirme notları ve CDS primlerinin değișkenliği üzerindeki etkisinin belirlenmesi önem arz etmektedir. Bu doğrultuda, 2008 krizinin etkilerinin de yer alması amacıyla, 01.01.2007 ile 22.04.2014 tarihleri arasında tespit edilen 127 olayın Türkiye'nin derecelendirme notlarındaki ve CDS primlerindeki değișim üzerinde var olan etkisi çoklu regresyon analizi yöntemi ile test edilmiștir.

Analiz sonuçları, kategorik olay sayısı bakımından, bağımlı değișkenler üzerinde etkiye sahip olan olay sayısı ile etkiye sahip olmayan olay sayısının birbirine yakın olduğunu göstermektedir. lyi ya da kötü olduğuna bakılmaksızın tüm olaylar değișkenler üzerinde beklendiği șekilde anlamlı bir etkiye sahiptir. Fakat olayların etkileri daha detaylı bir șekilde incelendiğinde, ortaya farklı bir tablo çıkmaktadır. Olayların anlamlı bir etkiye sahip olup olmadığı ve eğer anlamlı bir etkiye sahipse bu etkinin yönü, CDS 
primleri ile derecelendirme notları arasında ve hatta üç farklı kurulușun derecelendirme notları arasında dahi farklılık gösterebilmektedir. Siyasi ya da ekonomik olay anlamında bir değerlendirme yapıldığında, ekonomik olayların siyasi olaylara nazaran bağımlı değișkenler üzerinde daha etkili olduğu görülmektedir. Olay kaynakları göz önüne alınarak değerlendirildiğinde, yurt dıșı kaynaklı iyi olayların yurt içi kaynaklı iyi olaylara göre bağımlı değișkenler üzerinde daha etkili olduğu tespit edilmiștir. Tüm olaylar dikkate alınarak bir değerlendirme yapıldığında ise, derecelendirme notlarının CDS primlerine nazaran daha fazla olayın etkisini içeriğinde barındırdığı ifade edilebilir.

\section{KAYNAKÇA}

Büyüköztürk, Ș., 2012. Sosyal Bilimler İçin Veri Analizi El Kitabı, 16. Baskı, Ankara, Pegem Akademi.

Castellano, R. ve R. Giacometti, 2012. Credit Default Swaps: Implied Ratings Versus Official Ones, Research Paper, 10, 163-180.

Ersan, I. ve S. Günay, 2009. "Kredi Riski Göstergesi Olarak Kredi Temerrüt Swapları (CDSs) ve Kapatma Davasının Türkiye Riski Üzerine Etkisine Dair Bir Uygulama", Bankacılar Dergisi, 71, 3-22.

Finnerty, J.D., C.D. Miller ve R.R. Chen, 2013. The Impact of Credit Rating Announcements On Credit Default Swap Spreads, 37, 2011 1-2030.

Fitch Rating, 2014. Definitions of Ratings and Other Forms of Opinion.

Flannery, M.J., J.F. Houston ve F. Partnoy, 2010. Credit Default Swap Spreads as Viable Substitutes for Credit Ratings, University of San Diego School of Law, Legal Studies Research Paper Series, No: 10-31, 2084-21 23.

Gande, A. ve D.C. Parsley, 2005. "News Spillovers in the Sovereign Debt Market", Journal of Financial Economics, 75, 691-734.

Hull, J., M. Predescu ve A. White, 2004. "The Relationship between Credit Default Swap Spreads, Bond Yields, and Credit Rating Announcements", Journal of Banking \& Finance, 28, 2789-2811.

Ismailescu, I. ve H. Kazemi, 2010. "The Reaction of Market Credit Default Swap Spreads to Sovereign Credit Ratings Changes", Journal of Banking and Finance, 34, 2861-2873.

Jacobs, M., C.M. Peluso ve A.K. Karagözoğlu, 2010. Measuring Credit Risk: CDS Spreads vs. Credit Ratings. The 2010 FMA Meetings. 
Jensen, M.S. ve K.N. Daniels, 2005. "The Effect of Credit Ratings on Credit Default Swap Spreads and Credit Spreads", The Journal of Fixed Income, 15(3), 16-33.

Lehnert, T. ve F. Neske, 2006. "On the Relationship between Credit Rating Announcements and Credit Default Swap Spreads for European Reference Entities", Journal of Credit Risk, 2, 83-90.

Micu, M., E.M. Remolona ve P.D. Wooldridge, 2004. The Price Impact of Rating Announcements: Evidence from the Credit Default Swap Market, BIS Ouarterly Review, 55-66.

Micu, M., E.M. Remolona ve P.D. Wooldridge, 2006. The Price Impact of Rating Announcements: Which Announcements Matter?, BIS Working Papers, No: 207.

Moody's Investor Services, 2014. Rating Symbols and Definitions.

Norden, L. ve M. Weber, 2004. "Informational Efficiency of Credit Default Swap and Stock Markets: the Impact of Credit Rating Announcements", Journal of Banking \& Finance, 28, 2813-2843.

Papaioannou, G., 2011 . "Economic and Market Factors versus Credit Rating Announcements, on Credit Default Swap Spreads", International Journal of Economic and Finance, 3(5), 42-48.

Standard \& Poor's Rating Services,

https://www.globalcreditportal.com/ratingsdirect/renderArticle.do?articleld $=1019442 \&$ SctArtld $=147045 \&$ from $=$ CM\&nsl_code=LIME，Erișim Tarihi: 21 Mart 2014. 
